\title{
Bioeconomic efficiency of lamb finishing production systems
}

\section{Eficiência bioeconômica de sistemas de terminação de cordeiros}

\author{
Nielyson Junio Marcos Batista ${ }^{1}$; Patrícia Guimarães Pimentel ${ }^{2 *}$; José Alexandre \\ Agiova da Costa $^{3}$; Gelson Luís Dias Feijó ${ }^{3}$; Guilherme Rocha Moreira ${ }^{4}$; Rogério \\ César Pereira de Araújo ${ }^{2}$; Fernando Alvarenga Reis ${ }^{3}$; João Paulo Arcelino do \\ Rêgo ${ }^{5}$; Magno José Duarte Cândido ${ }^{2}$; Ivone Yurika Mizubuti ${ }^{6}$
}

\begin{abstract}
This study aimed to evaluate the production performance, quantitative carcass characteristics, and economic viability of lambs of genetic group Pantaneiro finished under four production systems: 1) Stockpiled Brachiaria brizantha cv piatã pasture; 2) Consortium of sorghum intercropped with Brachiaria brizantha cv piatã; 3) Feedlot based on sorghum silage and 2\% body weight energyprotein supplementation, 4) Feedlot based on sorghum silage and 4\% body weight energy-protein supplementation. Were used one hundred Pantaneiro lambs with an average body weight of $17.85 \pm$ $2.50 \mathrm{~kg}$ and at $70 \pm 15$ days of age, approximately. The average final body weight and total body weight gain of the animals finished on the consortium of sorghum intercropped with Brachiaria brizantha cv piatã were higher than those obtained with feedlot based on sorghum silage and $2 \%$ body weight energy-protein supplementation. However, when this system were compared with sorghum silage and $4 \%$ body weight energy-protein supplementation, these characteristics did not differ $(\mathrm{P}>0.05)$. Hot and cold carcass weights were lower when animals were fed sorghum silage and $2 \%$ body weight energyprotein supplementation as compared with the animals finished on the other systems. The greatest hot $(48.20 \%)$ and cold $(45.83 \%)$ carcass yields were observed in animals finished on sorghum silage and $4 \%$ body weight energy-protein supplementation. For the carcass compactness index, animals that received sorghum silage and $4 \%$ body weight energy-protein supplementation obtained higher values than those observed for $2 \%$ of supplementation. The economic evaluation showed a great return for the finishing systems, except for sorghum silage and $4 \%$ body weight energy-protein supplementation, and concluded that finishing lambs in a crop-livestock integration system presented a higher benefit/ cost ratio (1.61). Therefore, based on the conditions under which this study was conducted, the croplivestock integration is the most viable system for finishing lambs.
\end{abstract}

Key words: Crop-livestock integration. Feedlot. Grazing. Sheep.

1 Discente, Curso de Doutorado, Programa de Pós-Graduação de Integrado em Zootecnia, Universidade Federal do Ceará, UFC, Fortaleza, CE, Brasil. E-mail: nielyson@gmail.com

2 Profs. Drs., UFC, Fortaleza, CE, Brasil.E-mail: pgpimentel@hotmail.com; rcpa@ufc.br; magno@ufc.br

3 Pesquisadores, Empresa Brasileira de Pesquisa Agropecuária, EMBRAPA Gado de Corte, Campo Grande, MS, Brasil. E-mail: alexandre.agiova@embrapa.br; gelson.feijo@embrapa.br; fernando.a.reis@hotmail.com

4 Prof. Dr., Universidade Federal Rural de Pernambuco, UFRPE, Recife, PE, Brasil. E-mail:guirocham@gmail.com

5 Prof. Dr., Instituto Federal da Educação, Ciência e Tecnologia do Ceará, IFCE, Boa Viagem, CE, Brasil. E-mail: joaopaulo. rego@gmail.com

6 Prof ${ }^{\mathrm{a}} \mathrm{Dr}^{\mathrm{a}}$., Departamento de Zootecnia, Universidade Estadual de Londrina, UEL, Londrina, PR, Brasil. E-mail: mizubuti@uel. br

Author for correspondence

Received: Mar. 17, 2017 - Approved: Mar. 05, 2018 


\section{Resumo}

Avaliou-se o desempenho produtivo, características quantitativas das carcaças e viabilidade econômica de cordeiros do grupamento genético Pantaneiro, terminados em quatro sistemas de produção: 1) Pastagem vedada de Brachiaria brizantha cv piatã; 2) Pastagem de Brachiaria brizantha cv piatã em plantio consorciado com sorgo; 3) Confinamento a base de silagem de sorgo e suplementação energéticoproteica fornecida na proporção de $2 \%$ do peso corporal; 4) Confinamento a base de silagem de sorgo e suplementação energético-proteica fornecida na proporção de $4 \%$ do peso corporal. Foram utilizados cem cordeiros Pantaneiros com peso médio de $17,85 \pm 2,50 \mathrm{~kg} \mathrm{e} 70 \pm 15$ dias de idade, aproximadamente. O peso corporal médio final e o ganho de peso corporal total dos animais terminados em consórcio de sorgo com Brachiaria brizantha cv piatã foram superiores aos obtidos com o confinamento a base de silagem de sorgo e suplementação energético-proteica na razão de $2 \%$ do peso corporal. No entanto, quando comparados com o confinamento a base de silagem de sorgo e suplementação energético-proteica na razão de $4 \%$ do peso corporal, essas características não diferiram $(\mathrm{P}>0,05)$. Os pesos de carcaça quente e fria foram inferiores para os animais alimentados com silagem de sorgo e suplementação energética-proteica na razão de $2 \%$ do peso corporal em comparação com os animais terminados nos outros sistemas. Os maiores rendimentos de carcaça quente $(48,20 \%)$ e fria $(45,83 \%)$ foram observados nos animais terminados com silagem de sorgo e suplementação energético-proteica na razão de $4 \%$ do peso corporal. Para o índice de compacidade da carcaça, os animais que receberam silagem de sorgo e $4 \%$ de suplementação energético-proteica com relação ao peso corporal obtiveram valores maiores do que os observados com $2 \%$ de suplementação. A avaliação econômica mostrou que houve um ótimo retorno econômico para os sistemas de terminação, exceto para o sistema de terminação com pasto vedado, e concluiu que a terminação de cordeiros em integração lavoura pecuária relação de benefício/ custo superior $(1,61)$. Portanto, baseado nas condições em que foi conduzido o estudo, a integração lavoura pecuária apresenta-se como o sistema mais viável para terminação de cordeiros.

Palavras-chave: Confinamento. Integração lavoura pecuária. Ovinos. Pastejo.

\section{Introduction}

In modern sheep farming, the finishing system has received special attention for exerting a major influence on obtaining a high-quality end product - the meat. Several factors can influence the quality of sheep meat, such as age, sex, nutrition, distribution of fat, muscle functionality, stress, and production system. In the finishing stage, the goal is the production of a standardized carcass with adequate quantitative and qualitative characteristics compatible with the demand of the consumer market. However, most products derived from sheep meat still originate from low-quality carcasses, from older animals, which creates food taboos among consumers (ALMEIDA JÚNIOR et al., 2004).

The economic viability of a sheep production system is grounded on a number of factors such as feed conversion, management, efficient health control, ideal slaughter age, accessible price of inputs, and sale price compatible with the sensory traits of the meat from the produced carcasses. However, an extra cost is added when more technicized production systems are used, such as the feedlot and the use of cultivated pastures, although they promote a faster return of the invested capital by reducing the finishing time. In another aspect, systems integrating production of grains and animals, known as crop-livestock integration, have emerged. The crop-livestock integration has shown to be a viable alternative in the finishing stage of lamb for providing greater herbage allowance in quantity and quality throughout the year, as well as because of animal component, the sheep, which has a shorter production cycle as compared with cattle. In this regard, the economic viability of these systems should be analyzed in order to identify those that yield the best financial returns. Therefore, the aim of the present study was to evaluate the finishing stage of lambs in different production 
systems on their performance, quantitative carcass characteristics and economic viability.

\section{Material and Methods}

The climatic pattern of the region is described, according to the Köppen classification, as belonging to the range between $\mathrm{Cfa}$ and Aw, a tropical humid type.

The experimental design was completely randomized, consisting of four treatments (production systems): 1) Stockpiled Brachiaria brizantha cv piatã pasture (SPP); 2) Consortium of sorghum intercropped with Brachiaria brizantha $\mathrm{cv}$ piatã (IPP); 3) Feedlot based on sorghum silage and $2 \%$ body weight energy-protein supplementation (FL2); and 4) Feedlot based on sorghum silage and $4 \%$ body weight energy-protein supplementation (FL4). The concentrate feed was composed of ground corn, soybean meal, urea, ammonium sulfate, and mineral salt (Table 1), and formulated, according to NRC (2007), so as to meet the nutritional level of $18 \%$ crude protein and $75 \%$ total digestible nutrients, allowing $200 \mathrm{~g}$ of average daily gain.

Table 1. Proximate composition of concentrated feed.

\begin{tabular}{cc}
\hline Ingredients & \% Dry matter \\
\hline Grain ground corn & 76.20 \\
Soybean meal & 18.54 \\
Urea & 0.94 \\
Ammonium sulfate & 0.94 \\
Mineral mixture & 3.38 \\
\hline
\end{tabular}

Twenty-five animals were used per finishing system, totaling 100 lambs (56 rams and 44 ewes) of Pantaneiro genetic group, at approximately $70 \pm$ 15 days of age and with an average body weight of $17.85 \pm 2.50 \mathrm{~kg}$, identified by numbered earrings and distributed equally into the experimental systems.

The animals were weighed every two weeks to monitor their average daily gain and to adjust the concentrate feed and silage supplied. The duration of the experiment was determined based on the time necessary for the average of animals from one system to accumulate two millimeters of backfat in the carcass, which was the moment when males were slaughtered and females were sold. The backfat deposition was monitored by ultrasonography. In the pre-slaughter period, the animals were fasted for solids and liquids for 18 hours and weighed again to determine their body weight at slaughter.
The average daily gain (ADG) was calculated as the total weight gain divided by the number of days the animals remained in the systems.

Lambs were desensitized by stunning in the atlanto-occipital region, followed by bleeding by sectioning the carotid artery and jugular vein. Immediately after bleeding, the carcasses were skinned and eviscerated. The carcass was weighed to obtain the hot carcass weight (HCW), which was used to then calculate the hot carcass yield (HCY), as the division between $\mathrm{HCW}$ and body weight at slaughter. Subsequently, carcasses were transported to a cold room where they remained for 24 hours at $4^{\circ} \mathrm{C}$. After the chilling period, carcasses were weighed to determine the cold carcass weight (CCW). The cold carcass yield was calculated relation between $\mathrm{CCW}$ and body weight at slaughter, and expressed as percentage. Cooling loss (CL) was 
calculated as follows: CL $(\%)=[(\mathrm{HCW}-\mathrm{CCW}) /$ $\mathrm{HCW}] \times 100$.

The carcass was symmetrically divided into two halves by a longitudinal cut made by sectioning the ischio-pubic symphysis, following the body and the spinous process of the sacrum and lumbar and dorsal vertebrae. The left half-carcass was subdivided in seven anatomical regions, comprising the following meat cuts: shoulder, leg, rack, loin, ribs, neck, and flank steak according to the meat cutup procedures described by (GARCIA et al., 2003). The commercial cuts were weighed individually and the yield determinated as the percentage relative to the whole.

Using a tape measure, a ruler, and a compass, the following measurements were taken on the lambs' carcasses, according to Garcia et al. (2003): carcass external and internal lengths, leg length and circumference, rump width and circumference, and chest depth, width and circumference. The carcass and leg compactness indices were determined according to Cezar and Souza (2007).

The loin-eye area and the backfat thickness were determined using the left half-carcass, making a transverse cut between the 12 and $13^{\text {th }}$ ribs to expose the longissimus dorsi muscle area. The backfat thickness was obtained using a caliper, over the longissimus dorsi section (OSÓRIO; OSÓRIO, 2003). The loin-eye area was measured by outlining the muscle traced with a marker on tracing paper, superimposing the paper on the muscle in the previously selected area. Readings for loin-eye area were performed using a leaf area meter (LI-COR, model 3.100).

The data obtained during the experimental period served as basis for the calculation of the production costs referring to one year. Considering the particularities of each finishing system, the production cost of each system was calculated for comparison purposes. Fixed costs (depreciation, interest on average capital invested at the rate of
$6 \%$ per year, and maintenance and preservation at the rate of $2 \%$ on the average capital invested) and variable costs (feeding, medication and health, energy and fuel, purchase of animals, and labor) were considered. The effective operating cost, the total operating cost (TOC), the total cost, and the gross revenue (GR) composed the basis for the economic analysis (PAIM et al., 2011). The economic analysis was based on the calculation of the gross margin, which consists of the difference between gross revenue (GR) and the effective operating cost and on the obtention of the net margin (NM): NM = GR - TOC (SANTOS et al., 1997).

The gross revenue was generated from the sale of the lambs (US\$ $\times \mathrm{kg}$ body weight). For the consortium of sorghum intercropped with Brachiaria brizantha cv piatã, the gross revenue was generated from the sale of lambs and sale of the grain produced (the amount in kilograms of grain produced was stipulated according to the average obtained in the literature for the area utilized), while the effective operating costs comprised the explicit production costs referring to the purchase of the animals (US\$ $\times \mathrm{kg}$ body weight), feeding (concentrate and roughage), and expenses with medication, energy, fuel, and labor costs.

The first weighing, performed at the entry of the animals into the finishing systems, was used for the control of the production cost related to the amount of concentrate and silage supplied to them, allowing an estimate of how many kilograms of feed would be necessary for each animal to reach its slaughter weight.

For effective operating cost and total operating cost, the prices were quoted in the city of Campo Grande, MS, Brazil in the period from september to october of 2013. Feed costs were comprised of the prices and amounts provided in the fresh matter of the dietary ingredients. The costs with medication, energy, and fuel encompassed the prices and amounts used. Costs with labor were calculated based on the minimum wage table of 2013. 
The equipment, machinery, and facilities costs were quoted. For the calculation of depreciation, were adopted the difference between the acquisition price of the good and the residual value of the good divided by its useful life.

The benefit-cost ratio $(\mathrm{B} / \mathrm{C})$, obtained as $\mathrm{B} / \mathrm{C}=$ gross revenue/total cost, was applied to measure the return of each monetary unit applied in the activity. $\mathrm{A} B / \mathrm{C}$ ratio greater than one indicated a positive financial return (viable investment), while a $\mathrm{B} / \mathrm{C}$ ratio lower than one meant a negative financial return (unviable investment).

The four experimental systems were compared in terms of economic viability. The purchase price of the lambs was US\$2.21 per kilogram of body weight $\left(\mathrm{kg} \mathrm{BW}^{-1}\right)$, and their sale price was US\$ 2.87 $\mathrm{kg} \mathrm{BW}^{-1}$. These values were those adopted in the city of Campo Grande, MS, Brazil in the experimental period.

The studied variables were analyzed statistically using $\mathrm{SAEG}^{\circledR}$ software. For the quantitative variables, an analysis of variance was performed using the $\mathrm{F}$ test for comparison of means, considering the significance level of $5 \%$.

\section{Results and Discussion}

Sex influences several parameters, especially those related to deposition of distinct tissues of the body, reflecting in alterations in growth
(CARVALHO et al., 1999), but in this study, no effect of sex $(\mathrm{P}>0.05)$ was observed on the performance characteristics of the animals among the systems. Nevertheless, the animals used were slaughtered at approximately 150 day of age, before they reached puberty and, probably because they were too young, there was no opportunity for a difference in performance between the sexes to appear.

Mean values for final body weight, average daily gain and total weight gain of the animals finished on IPP were higher $(\mathrm{P}<0.05)$ than those obtained on FL2, while in the SPP and FL4 systems, these traits did not differ ( $\mathrm{P}>0.05$; Table 2). The significant difference observed for the these variables between IPP and FL2 might have stemmed from the quantitative restriction of the total ration in FL2. The supply of total ration for lambs finished on FL2, fed silage and concentrate at the respective concentrations of 1.5 and $2 \%$ of body weight, respectively, was below the minimum requirement of $4 \%$ of body weight for dry matter intake (NRC, 2007). This restriction possibly caused the lower weight gain observed in the animals finished on FL2. The adoption of feed restriction by sheep producers is influenced mainly by the benefit/cost ratio (BEN SALEM; SMITH, 2008). However, a balance point must be found so that the quality of the produced carcass is not compromised and so that sheep farmers can profit from their production (PEREIRA FILHO et al., 2005). 
Table 2. Average values of Pantaneiros lambs finished in different production systems.

\begin{tabular}{|c|c|c|c|c|c|}
\hline \multirow{2}{*}{ Variables } & \multicolumn{4}{|c|}{ Finishing systems $^{1}$} & \multirow{2}{*}{$\mathrm{CV}^{2}$} \\
\hline & SPP & IPP & FL2 & FL4 & \\
\hline Final body weigth $(\mathrm{kg})$ & $33.47^{\mathrm{ab}}$ & $33.07^{\mathrm{a}}$ & $28.30^{\mathrm{b}}$ & $30.96^{\mathrm{ab}}$ & 15.72 \\
\hline Avarage daily gain (g) & $0.14^{\mathrm{ab}}$ & $0.17^{\mathrm{a}}$ & $0.13^{\mathrm{b}}$ & $0.15^{\mathrm{ab}}$ & 27.81 \\
\hline Total weight gain $(\mathrm{kg})$ & $11.72^{\mathrm{ab}}$ & $13.49^{\mathrm{a}}$ & $10.09^{b}$ & $11.65^{\mathrm{ab}}$ & 28.33 \\
\hline Body weight at slaughter $(\mathrm{kg})$ & $31.44^{\mathrm{a}}$ & $31.07^{\mathrm{a}}$ & $26.26^{\mathrm{b}}$ & $28.88^{\mathrm{ab}}$ & 16.69 \\
\hline Fasted weight loss (\%) & $6.13^{\mathrm{b}}$ & $6.13^{\mathrm{b}}$ & $7.33^{\mathrm{a}}$ & $7.01^{\mathrm{ab}}$ & 17.23 \\
\hline Hot carcass weight (kg) & $13.69^{\mathrm{a}}$ & $13.83^{\mathrm{a}}$ & $11.71^{\mathrm{b}}$ & $13.92^{\mathrm{a}}$ & 17.48 \\
\hline Cold carcass weight (kg) & $13.16^{\mathrm{a}}$ & $13.20^{\mathrm{a}}$ & $11.16^{\mathrm{b}}$ & $13.25^{\mathrm{a}}$ & 17.96 \\
\hline Hot carcass yield (\%) & $43.52^{\mathrm{b}}$ & $44.53^{\mathrm{b}}$ & $44.64^{\mathrm{b}}$ & $48.20^{\mathrm{a}}$ & 5.14 \\
\hline Cold carcass yield (\%) & $41.59^{\mathrm{b}}$ & $42.51^{\mathrm{b}}$ & $42.55^{\mathrm{b}}$ & $45.83^{\mathrm{a}}$ & 5.01 \\
\hline Cooling loss (\%) & 4.42 & 4.53 & 4.67 & 4.1 & 31.03 \\
\hline Subcutaneous fat thickness (mm) & $1.47^{\mathrm{ab}}$ & $1.19^{b}$ & $1.43^{\mathrm{ab}}$ & $1.85^{\mathrm{a}}$ & 48.8 \\
\hline
\end{tabular}

${ }^{1}$ SPP: Stockpiled Brachiaria brizantha cv piatã, pasture; IPP: Consortium of sorghum intercropped with Brachiaria brizantha cv piatã; FL2: 2\% body weight energy-protein supplementation; and FL4: 4\% body weight energy-protein supplementation. ${ }^{2}$ Coefficient of variation (\%). Means followed by different letters in line have statistical difference by $\mathrm{F}$ test $(\mathrm{P}<0,05)$.

For the variable body weight at slaughter, the pasture-based finishing systems SPP and IPP yielded higher values as compared with FL2, but did not differ from FL4. The finishing system influenced hot carcass weight and cold carcass weight, with systems SPP, IPP, and FL4 providing higher weights than FL2. As regards the hot and cold carcass yields, the highest values were observed in FL4 (48.20 and $45.83 \%$, respectively). There was no influence of systems on cooling loss $(\mathrm{P} \geq 0.05)$, showing average value of $4.43 \%$. However, subcutaneous fat thickness was higher in FL4 than in IPP, though it did not differ from the other systems.

The difference $(\mathrm{P}<0.05)$ observed in fasted weight loss between lambs finished on FL2 and those finished on SPP and IPP might have been due to the lower energy input caused by the larger glucagon production by the pancreas, which in turn acts in the body reserves, mobilizing fat and muscle tissues for the energy supply via gluconeogenesis. Although the concentrations of glucagon in this study were not determined, this might have been one of the factors involved in the increased fasting losses of lambs finished on FL2.
Production of heavier animals with standardized carcasses, with maximum muscularity and an adequate amount of backfat, is directly related to the production system in which they were reared and mainly to the finishing stage. In addition to increasing the stocking rate of the property, feedlot-finishing systems improve the quantitativequalitative characteristics of feeding conditions of animals, which are ready for slaughter during the off-season (FRESCURA et al., 2005). By contrast, pasture-based finishing systems are aimed at the management and optimization of forage harvest by the animal, which, associated with the selective capacity of sheep, converge to the production of a carcass that meets the requirements of the consumer market (PRACHE et al., 2005).

In this study, the highest hot carcass weight and cold carcass weight were observed in the systems in which the feed was not restricted (SPP, IPP and FL4), which corroborates the performance data, since they are closely related to the carcass characteristics found in these animals (Table 2). The restricted feed supply to the animals on FL2 might have resulted in lower daily energy and protein input in the lambs' 
feeding. The hot and cold carcass yields are closely related to body weight at slaughter and to the yields of the non-carcass components. On the other hand, the lambs that received more concentrate (FL4) possibly obtained higher energy and protein density, and thus, there might have been a greater accumulation of muscle and fat tissues. Possibly, the higher available energy from the diet supplied provided an increase in propionate content, which in turn stimulated the insulin synthesis, inducing fat deposition in the carcass. Moreover, in high-starch concentrate diets, there is a greater escape of starch from rumen fermentation to be digested in the intestine and consequently used as a direct source of glucose (LÓPEZ; STUMPF JÚNIOR, 2000).

The finishing systems did not influenced the weight and yield of the commercial cuts of carcass of Pantaneiro lambs ( $\mathrm{P}>0.05$; Table 3 ). Ideal weight for each cut is one in which its value is maximal for both the producer and the consumer. In the present study, it was found that the genotype, sexual class, age at animal slaughter and feed system influence the carcass yield and consequently the yield of commercial cuts (OSÓRIO, 1992; HASHIMOTO et al., 2012).

The highest carcass external and internal lengths were found in animals finished on the deferred pasture (SPP) when compared with FL2; however, these measurements did not differ from those observed on IPP (Table 4). There was no influence of finishing system on leg length and circunference ( $\mathrm{P}>0.05)$, with average values of 35.84 and 28.28 $\mathrm{cm}$, respectively. Rump width and circumference, by contrast, were higher in the animals finished on IPP as compared with FL2, but did not differ from the other systems. The chest width and circunference measurements of the animals finished on SPP were higher than those obtained with FL2, but statistically similar to those of the other systems.

Table 3. Average values and percentages by weight of commercial cuts of carcass of Pantaneiros lambs finished in different production systems.

\begin{tabular}{|c|c|c|c|c|c|}
\hline \multirow{2}{*}{ Variables } & \multicolumn{4}{|c|}{ Finishing systems ${ }^{1}$} & \multirow{2}{*}{$\mathrm{CV}^{2}$} \\
\hline & SPP & IPP & FL2 & FL4 & \\
\hline Shoulder (kg) & 1.05 & 1.09 & 0.92 & 1.12 & 22.85 \\
\hline Shoulder (\%) & 17.32 & 17.84 & 17.64 & 17.96 & 10.30 \\
\hline Leg (kg) & 2.00 & 2.17 & 1.79 & 2.14 & 21.66 \\
\hline Leg $(\%)$ & 33.15 & 35.30 & 34.28 & 34.40 & 9.18 \\
\hline Loin $(\mathrm{kg})$ & 0.49 & 0.49 & 0.46 & 0.45 & 32.40 \\
\hline Loin $(\%)$ & 8.17 & 8.15 & 08.27 & 7.33 & 23.17 \\
\hline Rack (kg) & 0.82 & 0.81 & 0.69 & 0.91 & 27.63 \\
\hline Rack (\%) & 13.49 & 13.19 & 13.22 & 14.31 & 13.73 \\
\hline Ribs (kg) & 0.80 & 0.70 & 0.66 & 0.81 & 28.77 \\
\hline Ribs (\%) & 13.01 & 11.39 & 12.66 & 12.78 & 17.43 \\
\hline Flanc steak $(\mathrm{kg})$ & 0.34 & 0.32 & 0.29 & 0.35 & 29.27 \\
\hline Flanc steak (\%) & 5.56 & 5.19 & 5.41 & 5.46 & 16.28 \\
\hline Neck (kg) & 0.56 & 0.55 & 0.43 & 0.49 & 29.91 \\
\hline Neck $(\%)$ & 9.30 & 8.94 & 8.50 & 7.76 & 25.25 \\
\hline
\end{tabular}

${ }^{1}$ SPP: Stockpiled Brachiaria brizantha cv piatã, pasture; IPP: Consortium of sorghum intercropped with Brachiaria brizantha cv piatã; FL2: 2\% body weight energy-protein supplementation; and FL4: 4\% body weight energy-protein supplementation. ${ }^{2}$ Coefficient of variation (\%). 
Table 4. Average values measures of carcass of Pantaneiros lambs finished in different production systems.

\begin{tabular}{|c|c|c|c|c|c|}
\hline \multirow{2}{*}{ Variables $(\mathrm{cm})$} & \multicolumn{4}{|c|}{ Finishing systems $^{1}$} & \multirow{2}{*}{$\mathrm{CV}^{2}$} \\
\hline & SPP & IPP & FL2 & FL4 & \\
\hline Carcass external length & $68.00^{\mathrm{a}}$ & $67.08^{\mathrm{ab}}$ & $61.82^{\mathrm{c}}$ & $64.42^{\mathrm{bc}}$ & 05.99 \\
\hline Carcass internal length & $61.30^{\mathrm{a}}$ & $59.54^{\mathrm{ab}}$ & $57.18^{\mathrm{b}}$ & $56.96^{\mathrm{b}}$ & 05.35 \\
\hline Leg lenght & 36.40 & 36.00 & 35.25 & 35.67 & 04.52 \\
\hline Leg circunference & 28.80 & 28.92 & 27.36 & 28.04 & 06.92 \\
\hline Rump width & $17.85^{\mathrm{a}}$ & $17.79^{\mathrm{a}}$ & $16.57^{\mathrm{b}}$ & $17.79^{\mathrm{a}}$ & 08.44 \\
\hline Rump circunference & $54.70^{\mathrm{ab}}$ & $55.41^{\mathrm{a}}$ & $51.89^{b}$ & $54.67^{\mathrm{ab}}$ & 06.38 \\
\hline Chest depth & $26.70^{\mathrm{a}}$ & $25.79^{\mathrm{ab}}$ & $25.58^{\mathrm{ab}}$ & $24.68^{\mathrm{b}}$ & 06.05 \\
\hline Chest width & $20.70^{\mathrm{a}}$ & $20.13^{\mathrm{ab}}$ & $18.86^{\mathrm{b}}$ & $19.67^{\mathrm{ab}}$ & 10.42 \\
\hline Chest circunference & $70.10^{\mathrm{a}}$ & $69.42^{\mathrm{a}}$ & $65.64^{\mathrm{b}}$ & $68.95^{\mathrm{a}}$ & 05.16 \\
\hline Carcass compactness index & $0.21^{\mathrm{ab}}$ & $0.22^{\mathrm{a}}$ & $0.20^{\mathrm{b}}$ & $0.23^{\mathrm{a}}$ & 14.3 \\
\hline Leg compactness index & 0.49 & 0.49 & 0.46 & 0.49 & 8.87 \\
\hline Loin-eye area $\left(\mathrm{cm}^{3}\right)$ & 10.58 & 10.86 & 9.69 & 10.75 & 20.08 \\
\hline
\end{tabular}

${ }^{1}$ SPP: Stockpiled Brachiaria brizantha cv piatã, pasture; IPP: Consortium of sorghum intercropped with Brachiaria brizantha cv piatã; FL2: 2\% body weight energy-protein supplementation; and FL4: 4\% body weight energy-protein supplementation. ${ }^{2}$ Coefficient of variation (\%). Means followed by different letters in line have statistical difference by $\mathrm{F}$ test $(\mathrm{P}<0,05)$.

The differences observed for the variables chest depth, width and circumference are possibly related to the finishing system, given that animals finished on pasture usually have a heavier gastrointestinal tract, requiring greater bending of the ribs. Besides, the rib is a cut with large fat deposition, and so animals fed high-energy diets usually have greater fat deposition, resulting in a larger carcass diameter. Another factor that might have contributed to the difference observed in chest depth is cold carcass weight, as it influences the carcass morphology, since these measures are closely related.

The highest value for carcass compactness indices was observed with IPP and FL4 in relation to FL2, though it did not differ from SPP. No influence was observed for leg compactness indices or loin-eye area measurements $(\mathrm{P}>0.05)$, with average values of 0.48 and $10.47 \mathrm{~cm}$, respectively. However, the statistical difference observed in the carcass compactness index of lambs indicates that the finishing system played an important role in the distribution of meat by area, corroborating with the differences observed for cold carcass weight (13.16; 13.20 and $13.25 \mathrm{~kg}$, respectively for pasture stockpiled, crop-livestock integration and feedlot based on sorghum silage and $4 \%$ body weight energy-protein supplementation in relation feedlot based on sorghum silage and $2 \%$ body weight energy-protein supplementation, 11.16 $\mathrm{kg}$ ). According Alves et al. (2013), morphometric measurements of the sheep carcass, between chest width and leg and rump circunferences, can be used to predict average daily weigth gain and carcass yields, so as comercial cuts. Heavier carcasses have higher compactness indices (OSÓRIO, 1992). The measurements taken on the carcass allow us to predict traits that provide the best percentages of muscle, yield, conformation, and proportion of desirable cuts for the meat industry (MURTA et al., 2009).

The lowest values for fixed costs were obtained with the crop-livestock integration system (Table 5). No differences were observed between FL2 and FL4, as the animals on these systems were under the same facility conditions. The components of the fixed production costs are the applied resources that do not incorporate completely into the short-term products (lamb and grains), participating in several subsequent production cycles (PICOLLI et al., 
2013). This fact can be explained by the structure level of the system and the number of productive cycles in it, because these costs are diluted as the production cycles and the size of the area for lamb production are increased. Although the interest rate on the average capital invested (interest and inflation) was the same for all production systems $(0.6 \%)$, the higher values observed in the feedlot (76.42 and $85.10 \%$ higher than stockpiled pasture and crop-livestock integration, respectively) were stem from the greater capital invested for the formation of these systems (Tabela 5).

Table 5. Components of fixed costs of termination of Pantaneiro lambs finished in different production systems.

\begin{tabular}{llcccc}
\hline \multirow{2}{*}{ Components } & \multirow{2}{*}{ Units } & \multicolumn{4}{c}{ Finishing systems $^{1}$} \\
\cline { 3 - 5 } & & SPP & IPP & FL2 & FL4 \\
\hline Depreciation & US\$ & 182.00 & 241.81 & 569.66 & 569.66 \\
IAIC $^{2}$ & US\$ & 403.21 & 343.33 & 562.29 & 562.29 \\
Maintenance & US\$ & 268.88 & 228.89 & 374.86 & 374.86 \\
Total & US\$ & 854.09 & 814.03 & $1,506.81$ & $1,506.81$ \\
\hline
\end{tabular}

${ }^{1} \mathrm{SPP}$ : Stockpiled Brachiaria brizantha cv piatã, pasture; IPP: Consortium of sorghum intercropped with Brachiaria brizantha cv piatã; FL2: 2\% body weight energy-protein supplementation; and FL4: 4\% body weight energy-protein supplementation. ${ }^{2}$ Interest on average capital invested (rate of $0.6 \%$ per year).

In the analysis of variable costs, the SPP system had the lowest values (Table 6). The variable production costs are composed of expenses proportional to production, such as feeding, energy, fuel, labor costs, and purchase of animals and medications. The feed costs in feedlot production systems are higher as compared with finishing on pasture. The feedlot in most livestock holdings represents a decrease in slaughter age, production, and sale of animals with uniform carcass weight; however, these benefits are linked to greater investment, by producers, in feeding and labor. Therefore, lack of dietary planning and an imbalance of dietary components may imply production costs that result in financial unviability. The results depend on the supply of adequate feed and the weight gain capacity of the breed (NOGUEIRA, 2004). The cost with medications was higher in the systems in which the animals were kept in confinement, because they had a larger number of production cycles and consequently more animals produced over the year.

Table 6. Components of the variable costs of termination of Pantaneiro lambs finished in different production systems.

\begin{tabular}{lccccc}
\hline \multirow{2}{*}{ Components } & \multirow{2}{*}{ Units } & \multicolumn{4}{c}{ Finishing systems $^{1}$} \\
\cline { 3 - 6 } & & SSP & IPP & FL2 & FL4 \\
\hline Feeding & US\$ & 203.03 & 406.65 & 736.90 & 1.232 .42 \\
Sanity & US\$ & 6.08 & 10.82 & 16.57 & 16.57 \\
Energy and fuel & US\$ & 14.80 & 24.41 & 52.47 & 52.47 \\
Purchase of animals & US\$ & 939.02 & $1,878.05$ & $2,817.07$ & $2,817.07$ \\
Labor & US\$ & 240.74 & 240.74 & 481.49 & 481.49 \\
Total & US\$ & $1,403.67$ & $2,560.67$ & $4,104.50$ & $4,600.02$ \\
\hline
\end{tabular}

${ }^{1} \mathrm{SPP}$ : Stockpiled Brachiaria brizantha cv piatã, pasture; IPP: Consortium of sorghum intercropped with Brachiaria brizantha cv piatã; FL2: 2\% body weight energy-protein supplementation; and FL4: 4\% body weight energy-protein supplementation. 
Table 7 contains the centesimal composition of dietary ingredients. the concentrate diet and the purchase price of the

Table 7. Chemical composition and acquisition values (US\$) of dietary ingredients of the concentrated feed used in termination of Pantaneiro lambs finished in different production systems.

\begin{tabular}{lccc}
\hline \multicolumn{1}{c}{ Ingredient } & Proportion $(\%$ natural matter $)$ & Price $\left(\mathrm{US \$} \mathrm{kg}^{-1}\right)$ & Total cost $\left(\mathrm{US} \$ \mathrm{~kg}^{-1}\right)$ \\
\hline Grain ground corn & 76.14 & 0.16 & 0.12 \\
Soybean meal & 18.64 & 0.41 & 0.06 \\
Ammonium sulfate & 0.91 & 0.20 & 0.01 \\
Urea & 0.91 & 0.62 & 0.01 \\
Mineral mixture & 3.40 & 0.77 & 0.02 \\
Total cost $\left(\mathrm{US} \$ \mathrm{~kg}^{-1}\right)$ & 1 & - & 0.31 \\
\hline
\end{tabular}

The integration of livestock with grain production generated another source of return, with the sale of the grains, on the invested capital to this system. As stated by Fontaneli et al. (2000), in the integrated system, the revenue per area is increased as compared with unintegrated systems, because the integration of crop and livestock provides an additional source of income, compared with other systems. This is because of the continuous use of agricultural areas, the increased plant and animal yield, and the reduction of production costs brought about by the biological advantages (BALBINOT
JÚNIOR et al., 2009).

Concerning to the economic indicators, were obtained lower effective and total operating costs and total cost in SPP as compared with the other systems, and these costs increased as the systems required better improvements, feed, labor, and provided a higher number of finished animals (Table 8). The cost per kilogram of body weight produced was lowest in IPP (1.63 US\$ $\mathrm{kg}^{-1}$ ), because this system allowed another source of income with the integration of crop and livestock in the same area.

Table 8. Economic indicators of termination of Pantaneiro lambs finished in different production systems.

\begin{tabular}{lccccc}
\hline \multirow{2}{*}{ Indicators } & \multirow{2}{*}{ Unit } & \multicolumn{4}{c}{ Finishing systems $^{1}$} \\
\cline { 3 - 6 } & & SPP & IPP & FL2 & FL4 \\
\hline Gross revenue & US\$ & $2,139.87$ & $5,428.67$ & $6,031.85$ & $6,353.55$ \\
Effective operating cost & US\$ & $1,403.67$ & $2,560.67$ & $4,104.5$ & $4,600.02$ \\
Total operating cost & US\$ & $1,851.55$ & $3,030.38$ & $5,049.02$ & $5,556.47$ \\
Total cost & US\$ & $2,254.87$ & $3,373.72$ & $5,611.30$ & $6,106.83$ \\
Cost per kg body weight produced & US\$ & 1.88 & 1.63 & 1.95 & 2.08 \\
Purchase price & US\$ & 2.21 & 2.21 & 2.21 & 2.21 \\
Sale price & US\$ & 2.87 & 2.87 & 2.87 & 2.87 \\
Gross margin & US\$ & 739.19 & $2,867.98$ & $1,927.34$ & $1,753.52$ \\
Net margin & US\$ & 288.32 & $2,398.28$ & 982.83 & 809.00 \\
B/C & $\%$ & 0.95 & 1.61 & 1.07 & 1.04 \\
\hline
\end{tabular}

${ }^{1}$ SPP: Stockpiled Brachiaria brizantha cv piatã, pasture; IPP: Consortium of sorghum intercropped with Brachiaria brizantha cv piatã; FL2: 2\% body weight energy-protein supplementation; and FL4: 4\% body weight energy-protein supplementation. ${ }^{2}$ Benefitcost ratio. 
The greatest gross margin was observed in the IPP system as compared with the other production systems. This variable is influenced by gross revenue and effective operating cost, i.e., systems with higher revenues and lower costs lead to a higher gross margem. This assertion corroborates the data obtained in the study. In this way, the return of the money invested in the said system represents a situation of production losses.

The benefit/cost analysis showed that the IPP system provided greater return on invested capital, and also that, in the conditions evaluated, SPP was not a good option for finishing lambs, given that the benefit-cost ratio for this system was negative.

The difference in management between the production systems that occurred during the finishing stage was responsible for the differences observed in production costs. In this study, the price of acquisition of the animals contributed with approximately $70 \%$ of the effective operating costs of the production system. The acquisition of lambs and feeding are the components of largest participation in production costs (NOGUEIRA, 2005). The lower need for labor influenced the reduction in the production costs. In the systems evaluated in this study, effective operating cost represented approximately $70 \%$ of the total production cost.

\section{Conclusion}

The crop-livestock integration is the most viable system for finishing lambs. The finishing stage of lambs associated with grain production provid a synergy of efforts, with economic and productive benefits.

\section{Acknowledgments}

To the staff of the Brazilian Agricultural Research Corporation - EMBRAPA for the opportunity to develop this research.

\section{References}

ALMEIDA JÚNIOR, G. A.; COSTA, C.; MONTEIRO, A. L. G.; GARCIA, C. A.; MUNARI, D. P.; NERES, M. A. Qualidade de carne de cordeiros criados em creep feeding com silagem de grãos úmidos de milho. Revista Brasileira de Zootecnia, Viçosa, MG, v. 33, n. 4, p. 10391047, 2004.

ALVES, D. D.; ARAÚJO, L. M.; MONTEIRO, H. C. F.; LEONEL, F. P.; SILVA, F. V.; SIMÕES, D. A.; GONÇALVES, W. C.; BRANT, L. M. S. Carcass characteristics, non-carcass components and morphometry in sheep submitted to different supplementation strategies. Semina: Ciências Agrárias, Londrina, v. 34, n. 6, p. 3093-3104, 2013.

BALBINOT JÚNIOR, A. A.; MORAES, A.; VEIGA, M.; PELISSARI, A.; DIECKOW, J. Integração lavourapecuária: intensificação de uso de áreas agrícolas. Ciência Rural, Santa Maria, v. 39, n. 6, p. 1925-1933, 2009.

BEN SALEM, H.; SMITH, T. Feeding strategies to increase small ruminant production in dry environments. Small Ruminant Research, Arkansas, v. 77, n. 2-3, p. 174-194, 2008.

CARVAlHO, S.; PIRES, C. C.; PERES, J. R. R.; ZEPPENFELD, C.; WEISS, A. Desempenho de cordeiros machos inteiros, machos castrados e fêmeas, alimentados em confinamento. Ciência Rural, Santa Maria, v. 29, n. 1, p. 129-133, 1999.

CEZAR, M. F.; SOUSA, W. H. Carcaças ovinas e caprinas: obtenção, avaliação, classificação. Uberaba: Editora Agropecuária Tropical, 2007. 232 p.

FONTANELI, R. S.; AMBROSI, I.; SANTOS, H. P.; IGNACZAK, J. C.; ZOLDAN, S. M. Análise econômica de sistemas de produção de grãos com pastagens anuais de inverno, em sistema de plantio direto. Pesquisa Agropecuária Brasileira, Brasília, v. 35, n. 11, p. 21292137, 2000.

FRESCURA, R. B. M.; PIRES, C. C.; ROCHA, M. G. D.; SILVA, J. H. S. D.; MÜLLER, L. Sistemas de alimentação na produção de cordeiros para abate aos 28 kg. Revista Brasileira de Zootecnia, Viçosa, MG, v. 34, n. 4, p. 1267-1277, 2005.

GARCIA, C. A.; MONTEIRO, A. L. G.; COSTA, C.; NERES, M. A.; ROSA, G. J. M. Medidas objetivas e composição tecidual da carcaça de cordeiros alimentados com diferentes níveis de energia em creep feeding. Revista Brasileira de Zootecnia, Viçosa, MG, v. 32, n. 6, p. 1380-1390, 2003.

HASHIMOTO, J. H.; OSÓRIO, J. C. S.; OSÓRIO, M. T. M.; BONACINA, M. S.; LEHMEN, R. I.; PEDROSO, 
C. E. S. Qualidade de carcaça, desenvolvimento regional e tecidual de cordeiros terminados em três sistemas. Revista Brasileira de Zootecnia, Viçosa, MG, v. 41, n. 2, p. 438-448, 2012.

LÓPEZ, J.; STUMPF JÚNIOR, W. S. Influência do grão de sorgo como fonte de amido em ovinos alimentados com feno. Parâmetros plasmáticos. Revista Brasileira de Zootecnia, Viçosa, MG, v. 29, n. 4, p. 1183-1190, 2000.

MURTA, R. M.; CHAVES, M. A.; SILVA, F. V.; BUTERI, C. B.; FERNANDES, O. W. B.; SANTOS, L. X. Ganho em peso e características da carcaça de ovinos confinados alimentados com bagaço de cana hidrolisado com óxido de cálcio. Ciência Animal Brasileira, Goiânia, v. 10, n. 2, p. 438-445, 2009.

NATIONAL RESEARCH COUNCIL - NRC. Nutrient requirements of small ruminants: sheep, goats, cervids and new world camelids. Washington: National Academy Press, 2007. 384 p.

NOGUEIRA, M. P. Confinamento em 2005. Bebedouro, SP: Scot Consultoria, 2005. 615 p. (Comunicado técnico, 1).

Gestão de custos e avaliação de resultados. Bebedouro, SP: Scot Consultoria, 2004. 219 p.

OSÓRIO, J. C. S. Estudio de la calidad de canales comercializadas en el tipo ternasco segun la procedencia: bases para la mejora de dicha calidad en Brazil. 1992. Tese (Doutorado em Veterinária) - Facultad de Veterinaria da Universidad de Zaragoza, Zaragoza.
OSÓRIO, J. C. S.; OSÓRIO, M. T. M. Produção de carne ovina: técnicas de avaliação in vivo e na carcaça. Pelotas: Editora Universitária, 2003. 73 p.

PAIM, T. P.; CARDOSO, M. T. M.; BORGES, B. O.; GOMES, E. F.; LOUVADINI, H.; MCMANUS, C. Estudo econômico da produção de cordeiros cruzados confinados abatidos em diferentes pesos. Ciência Animal Brasileira, Goiânia, v. 12, n. 1, p. 48-57, 2011.

PEREIRA FILHO, J. M.; RESENDE, K. T.; TEXEIRA, I. A. M. A.; SILVA SOBRINHO, A. G.; YÂNEZ, E. A.; FERREIRA, A. C. D. Efeito da restrição alimentar no desempenho produtivo e econômico de cabritos F1 Boer x Saanen. Revista Brasileira de Zootecnia, Viçosa, MG, v. 34, n. 1, p. 188-196, 2005.

PICOLLI, M.; CORRÊA, G. F.; ROHENKOHL, J. E.; TONTIN, J. F.; MOREIRA, S. M.; ROSSATO, M. V. Viabilidade econômica de um sistema de terminação de cordeiros em confinamento na região da campanha/RS. Revista Eletrônica em Gestão, Educação e Tecnologia Ambiental, Santa Maria, v. 11, n. 11, p. 2493-2505, 2013.

PRACHE, S.; CORNU, A.; BERDAGUÉ, J. L.; PRIOLO, A. Traceability of animal feeding diet in the meat and milk of small ruminants. Small Ruminant Research, Arkansas, v. 59, n. 2-3, p. 157-168, 2005.

SANTOS, H. P.; FANCELLI, A. L.; ANDIA, L. H. Análise econômica de sistemas de rotação de culturas para trigo, num período de dois anos, sob sistema plantio direto. Pesquisa Agropecuária Brasileira, Brasília, v. 32, n. 11, p. 1111-1117, 1997. 